\title{
Persepsi Dukungan Organisasi dan Komitmen Afektif Organisasi: Peran Mediasi Keterikatan Karyawan pada Karyawan Pertelevisian
}

\author{
Nina Febriani Panuju, ${ }^{1}$ Wustari L. Mangundjaya ${ }^{2}$ \\ ${ }^{1,2}$ Fakultas Psikologi Universitas Indonesia, Depok - Indonesia
}

\begin{abstract}
Television broadcasting company has unique working condition with various challenges and demands to keep making innovations. This research aimed to study working conditions in television broadcasting companies in Indonesia using three variables, namely affective organization commitment (AOC), employee engagement (EE), and perceived organizational support (POS). The data were obtained by using 3 measurements, i.e. affective organization commitment scale, survey of perceived organizational support (SPOS), and Aon Hewitt Employee Engagement (AHEE). The respondents consisted of 139 employees of Indonesian television broadcasting companies which were obtained from convenience sampling with the criteria of being a permanent employee, having worked at least a year, and being 23-55 years old. Statistical techniques PROCESS that was developed by Hayes were applied to test the mediation role. The result showed that all variables were positively related and EE acted as partial mediator to correlation between POS and AOC.
\end{abstract}

Keywords: affective organization commitment; employee engagement; perceived organizational support; television broadcasting company

\begin{abstract}
Abstrak: Industri pertelevisian memiliki kondisi kerja yang unik dengan sejumlah tantangan dan tuntutan untuk terus berinovasi. Penelitian ini bertujuan untuk mengkaji bagaimana kondisi kerja di perusahaan pertelevisian di Indonesia dengan melibatkan tiga variabel penelitian, yaitu komitmen afektif organisasi, keterikatan karyawan dan persepsi dukungan organisasi. Data diperoleh melalui 3 alat ukur, yaitu affective organization commitment (AOC), survey of perceived organizational support (SPOS) dan Aon Hewitt Employee Engagement (AHEE). Responden adalah 139 orang karyawan pertelevisian yang diperoleh melalui convenience sampling dengan kriteria sebagai karyawan tetap, telah bekerja minimal setahun dan berusia 23-55 tahun. Teknik statistik PROCESS yang dikembangkan oleh Hayes digunakan untuk menguji analisis peran mediasi. Hasil penelitian menunjukkan semua variabel memiliki hubungan yang positif dan keterikatan karyawan memediasi secara parsial hubungan antara persepsi dukungan organisasi dengan komitmen afektif organisasi.
\end{abstract}

Kata Kunci: komitmen afektif organisasi; keterikatan karyawan; persepsi dukungan organisasi; perusahaan pertelevisian

Corresponding Author: Wustari L. Mangundjaya (e-mail: wustari@gmail.com). Program Studi Psikologi Profesi, Fakultas Psikologi Universitas Indonesia, Kampus UI Depok, Jl. Lkr. Kampus Raya Blok Mawar No. 5 Pondok Cina, Depok 16424. 


\section{Pendahuluan}

Pada tahun 2011, terjadi perubahan besar dalam industri pertelevisian di Indonesia dalam bentuk merger dan akuisisi (Nugroho, Putri, \& Laksmi, 2012). Perubahan ini menuntut sumber daya manusia (SDM) untuk terus berinovasi dalam menghasilkan program televisi yang baru dan berbeda. Hal ini memunculkan masalah terkait kondisi kerja di perusahaan pertelevisian seperti tuntutan kerja yang tinggi, tenggat waktu kerja yang sempit, jam kerja yang panjang, kurangnya penghargaan dari atasan dan kurangnya dukungan rekan kerja (Wardhana, 2018). Permasalahan ini kemudian meningkatkan risiko tekanan kerja pada karyawan pertelevisian, yang dapat menyebabkan rasa lelah secara fisik, kondisi psikologis yang tidak menyenangkan dan menurunnya performa kerja (Wardhana, 2018), bahkan dapat memicu pengunduran diri di perusahaan pertelevisian. Trans Corp sebagai salah satu perusahaan pertelevisian di Indonesia menyatakan bahwa sejak berdiri sudah ada 10.000 karyawan yang keluar masuk perusahaan tersebut (Sanusi, 2013).

Kondisi semacam dapat diatasi, salah satu caranya, dengan meningkatkan komitmen organisasi. Komitmen organisasi didefinisikan sebagai kondisi psikologis yang menggambarkan ikatan antara individu dengan organisasi dan memengaruhi keputusan individu untuk menetap atau meninggalkan organisasi (Meyer \& Allen, 1991). Komitmen organisasi diyakini dapat mengatasi sejumlah masalah terkait kondisi kerja seperti menurunkan tingkat pengunduran diri, ketidakhadiran, meningkatkan performa kerja dan kesejahteraan pekerja (Meyer \& Allen, 1997). Sebaliknya, individu yang tidak memiliki komitmen organisasi dapat mengalami alienation (Kobasa, Maddi, \& Kahn, 1982). Alienation dapat menyebabkan depersonalisasi (kehilangan iden- titas diri dalam organisasi) dalam bentuk perasaan tidak berdaya, mengasingkan diri, merasa tidak memiliki makna dalam pekerjaannya dan hal ini dapat memengaruhi performa kerja individu (O’Donohue \& Nelson, 2014).

Komitmen organisasi terdiri dari 3 komponen, yaitu komitmen afektif, komitmen normatif, dan komitmen kontinuans (Meyer \& Allen, 1987). Ketiga komponen komitmen organisasi tersebut digerakkan oleh motif yang berbedabeda. Komitmen afektif didasari oleh adanya keterlibatan emosi dan kelekatan internal individu terhadap organisasi (Meyer \& Allen, 1991). Komitmen normatif didasari oleh adanya tanggung jawab individu terhadap organisasi (Meyer \& Allen, 1991). Sementara komitmen kontinuans didasari oleh adanya pertimbangan mengenai kerugian yang akan muncul jika individu meninggalkan organisasi (Meyer \& Allen, 1991). Dari ketiga komponen ini, komitmen afektif merupakan komponen yang dianggap paling penting, karena merupakan inti dari komitmen organisasi (Mercurio, 2015), yang dianggap lebih menggambarkan dedikasi dan loyalitas pada perusahaan (Rhoades, Eisenberger, \& Armeli, 2001). Oleh sebab itu komitmen afektif organisasi menjadi variabel yang diteliti.

Komitmen afektif organisasi didefinisikan sebagai perasaan memiliki dan identifikasi (menjadi bagian dari diri seseorang) yang dapat meningkatkan keikutsertaan individu dalam kegiatan organisasi, dorongan untuk mewujudkan tujuan organisasi, dan keinginan untuk menetap di dalam organisasi (Meyer \& Allen, 1991). Komitmen afektif organisasi dapat memberikan dampak positif terhadap permasalahan kondisi kerja pada karyawan pertelevisian, antara lain dengan cara mengurangi tekanan kerja dengan menekan burnout atau kelelahan secara emosional (Schmidt, 2007). Selain itu, dampak positif 
lainnya adalah menurunkan risiko pengunduran diri (Meyer, Stanley, Herscovitch, \& Topolnytsky, 2002), menurunkan tingkat absensi karyawan (Eisenberger, Fasolo, \& Davis-LaMastro, 1990), individu dapat menghargai nilai-nilai perusahaan (Beheshtifar \& Herat, 2013), dan patuh pada norma dan praktik kebijakan organisasi (Jena, Bhattacharyya, \& Pradhan, 2017). Secara praktis, individu dengan komitmen afektif organisasi akan bekerja dengan sungguh-sungguh dan menampilkan performa kerja yang lebih baik (Meyer \& Allen, 1997).

Lebih lanjut, komitmen afektif organisasi juga diduga dipengaruhi oleh usia (Pourghaz, Tamini, \& Karamad, 2011). Beberapa peneliti mengemukakan bahwa faktor demografis seperti usia dan lama kerja turut memengaruhi komitmen organisasi (Azeem, 2010; Cohen, 1993; Meyer \& Allen, 1990). Selain itu, faktor lain yang dapat memengaruhi komitmen afektif organisasi adalah persepsi dukungan organisasi atau perceived organizational support (POS) (Eisenberger et al., 1990; Eisenberger, Huntington, Hutchison, \& Sowa, 1986; Meyer \& Allen, 1997; Rhoades et al., 2001). Persepsi dukungan organisasi didefinisikan sebagai keyakinan individu bahwa organisasi mengapresiasi hasil kerja dan menunjukkan kepedulian terhadap kesejahteraan karyawan (Eisenberger et al., 1986).

Persepsi dukungan organisasi diyakini dapat menumbuhkan tanggung jawab untuk mendukung organisasi mewujudkan tujuannya (Eisenberger, Armeli, Rexwinkel, Lynch, \& Rhoades, 2001). Hal ini juga mencakup upaya untuk mengambil peran tambahan (extra-role behavior) dengan cara membantu rekan kerja. Dengan membantu pekerjaan rekannya secara efektif, hal ini dapat mendukung organisasi mencapai tujuannya dengan lebih baik (Lynch, Eisenberger, \& Armeli, 1999; Rhoades \& Eisenberger, 2002; Rhoades et al., 2001).
Dampak persepsi dukungan organisasi terkait peran tambahan, tidak hanya dirasakan oleh karyawan dengan level jabatan bawah, tetapi juga dapat dirasakan oleh karyawan level manajer ke atas (Wayne, Shore, \& Liden, 1997). Penelitian tersebut menunjukkan bahwa manajer dengan persepsi dukungan organisasi yang tinggi memiliki kecenderungan untuk membantu pekerjaan karyawan yang sedang absen, mengarahkan karyawan baru untuk mengerjakan pekerjaannya, membantu karyawan lain yang sedang mengerjakan banyak pekerjaan dan menolong rekan kerja lainnya, meskipun tugas tersebut bukanlah tanggung jawab utamanya. Atasan yang menerima perlakuan secara adil dari organisasi akan memperlakukan bawahannya dengan baik (Tepper \& Taylor, 2003). Hal ini kemudian dapat memberikan hasil yang positif bagi karyawan, seperti mengurangi tekanan kerja dan meningkatkan performa kerja (Rhoades \& Eisenberger, 2002; Viswesvaran, Sanchez, \& Fisher, 1999).

Persepsi dukungan organisasi dapat dibentuk dengan cara memberikan rasa hormat, kompensasi, promosi, akses informasi, dan bentuk dukungan lainnya yang dapat membuat karyawan menjalankan tugasnya dengan lebih baik (Rhoades \& Eisenberger, 2002). Melalui persepsi dukungan organisasi, kebutuhan sosioemosional karyawan dapat dipenuhi, sehingga menumbuhkan tanggung jawab dan dukungan karyawan terhadap pencapaian tujuan organisasi (Eisenberger et al., 2001), serta kepuasan kerja dan mood positif (Rhoades \& Eisenberger, 2002). Selain itu, persepsi dukungan organisasi juga dapat memberikan keuntungan bagi perusahaan melalui meningkatnya komitmen afektif organisasi, performa kerja yang baik, serta menurunkan angka pengunduran diri (Rhoades \& Eisenberger, 2002).

Selain persepsi dukungan organisasi, faktor lain yang dapat memengaruhi komitmen afektif organisasi adalah keterikatan karyawan atau 
employee engagement (EE). Keterikatan karyawan dianggap sebagai salah satu anteseden atau faktor pemicu komitmen afektif organisasi (Posthuma, Campion, Masimova, \& Campion, 2013). Dalam hal ini keterikatan karyawan menggambarkan komitmen seseorang terhadap organisasi dan memengaruhi performa serta masa kerja (Federman, 2009). Teori keterikatan karyawan banyak berkembang dalam berbagai penelitian dan salah satu yang menjadi fokus pada penelitian ini adalah model keterikatan karyawan yang dikembangkan oleh (Hewitt Associates, 2004), karena dianggap paling cocok untuk menggambarkan kondisi industri pertelevisian saat ini. Selain itu, model ini juga tidak hanya menjelaskan keterikatan (engagement) sebagai bagian dari kondisi mental atau psikologis saja, tetapi juga menjelaskan keterikatan dalam bentuk perilaku yang dapat diamati dan diukur.

Keterikatan karyawan didefinisikan sebagai kondisi individu secara emosional dan intelektual yang berkomitmen pada organisasi, yang dapat diukur melalui 3 perilaku, yaitu say (individu secara konsisten mengatakan hal-hal positif tentang organisasinya), stay (keinginan individu untuk menetap di dalam organisasi), dan strive (karyawan melakukan usaha lebih yang mendukung keberhasilan organisasi) (Hewitt Associates, 2004). Lebih lanjut, keterikatan karyawan dapat menimbulkan gairah atau antusiasme terhadap pekerjaan, dedikasi dan dorongan untuk menyelesaikan tugas-tugas, menyebabkan individu bekerja dengan fokus atau penuh konsentrasi, bahkan tenggelam dalam pekerjaannya (Hewitt Associates, 2004).

Berdasarkan survei keterikatan karyawan yang dilakukan oleh Hewitt pada tahun 2018, ditemukan beberapa faktor pendorong keterikatan karyawan, yaitu kelincahan organisasi untuk beradaptasi terhadap tuntutan lingkungan (agility); kepemimpinan yang dapat meningkatkan keterikatan (engaging leadership) mencakup kepemimpinan senior dan manajer; pengembangan talent yang mencakup reputasi perusahaan (brand), pengembangan karir, performance management, penghargaan dan pengakuan (rewards and recognition), pengelolaan talent dan kepegawaian; kondisi kerja yang mencakup pemberdayaan atau otonomi kerja, tugas pekerjaan, keseimbangan antara kehidupan pribadi dengan pekerjaan (work life balance) dan kepuasan kerja; serta kebutuhan dasar yang harus dipenuhi mencakup keamanan kerja, pengelolaan risiko dan keselamatan, serta survei berkala yang dilakukan perusahaan terkait pengembangan berkala (Aon Hewitt, 2018).

Dampak dari keterikatan karyawan di antaranya, meningkatkan produktivitas kinerja individu, menurunkan angka pengunduran diri, menurunkan tingkat absensi, meningkatkan kepuasan atau kesetiaan pelanggan, serta meningkatkan keuntungan tahunan perusahaan (Ahlowalia, Tiwary, \& Jha, 2014). Hal ini didukung oleh survei yang dilakukan oleh Tower Watson's 2012 Global Workforce Study, yang menunjukkan bahwa organisasi yang mampu mengelola keterikatan karyawan dengan baik, memperoleh keuntungan tiga kali lipat dibandingkan perusahaan yang tidak mampu mengelola keterikatan karyawan (Ahlowalia et al., 2014). Sementara itu, individu yang tidak memiliki keterikatan (personal disengagement) dapat membawa dampak negatif seperti resisten terhadap tugas dan tanggung jawab; memiliki kepercayaan yang rendah terhadap organisasi; meyakini bahwa dirinya baik-baik saja dan orang lain yang bermasalah; ketidakmampuan untuk menemukan solusi dari sebuah masalah; memiliki komitmen yang rendah terhadap perusahaan, kelompok kerja, perannya dalam orga- 
nisasi; mengisolasi diri; tidak akan mengemukakan secara terbuka mengenai pandangan negatifnya, tetapi akan menunjukkan rasa frustrasinya, baik secara diam-diam maupun terus terang (Coffman, Gonzalez-Molina, \& Gopal, 2002).

ZLebih lanjut, individu yang memiliki keterikatan karyawan dapat menularkan hubungan yang positif dengan organisasi dan anggota di dalamnya (Kahn, 1990). Sejalan dengan teori social exchange, adanya hubungan mutual yang saling menghargai antara individu dengan organisasi inilah yang kemudian membentuk komitmen pada kedua belah pihak (Cropanzano \& Mitchell, 2005). Hal ini kemudian mengacu pada komitmen afektif organisasi (Jena et al., 2017). Selanjutnya, persepsi dukungan atasan, karakteristik pekerjaan, penghargaan dan pengakuan, serta keadilan distributif dan prosedural, yang merupakan bagian dari faktor pembentuk persepsi dukungan organisasi, turut berpengaruh terhadap keterikatan karyawan (Kahn, 1990). Penelitian lainnya menguatkan temuan empiris yang menunjukkan bahwa persepsi dukungan organisasi memiliki korelasi yang positif terhadap keterikatan karyawan (Dai \& Qin, 2016). Pada saat karyawan memperoleh persepsi bahwa organisasi memberikan dukungan, maka akan muncul tanggung jawab karyawan kepada perusahaan, sehingga mendorong karyawan untuk bekerja lebih keras guna mendapatkan suatu penghargaan dalam bentuk materi dan non materi (Dai \& Qin, 2016).

Berdasarkan penjabaran di atas mengenai komitmen afektif organisasi, persepsi dukungan organisasi, dan keterikatan karyawan, terlihat bahwa ketiga variabel tersebut memiliki korelasi satu sama lain secara positif. Komitmen afektif organisasi muncul ketika individu menganggap organisasi menjadi bagian dari dirinya (identifikasi). Hal ini dapat terjadi ketika individu memperoleh persepsi bahwa organisasi memberikan dukungan yang cukup dan menunjukkan kepeduliannya kepada individu melalui persepsi dukungan organisasi. Selanjutnya, melalui persepsi dukungan organisasi, juga dapat muncul perasaan keterikatan secara emosional pada organisasi. Hal ini menyebabkan individu memiliki keinginan untuk membalas jasa dengan cara bekerja sungguh-sungguh, guna membantu organisasi mencapai tujuannya (keterikatan karyawan). Saat karyawan memiliki keterikatan terhadap organisasi, semakin lama individu akan membangun komitmen afektif. Dengan demikian, peneliti menetapkan hipotesis, yaitu terdapat hubungan positif yang signifikan antara persepsi dukungan organisasi dengan komitmen afektif organisasi yang dimediasi oleh keterikatan karyawan. Berdasarkan hipotesis ini, peneliti kemudian menetapkan model penelitian seperti pada Gambar 1.

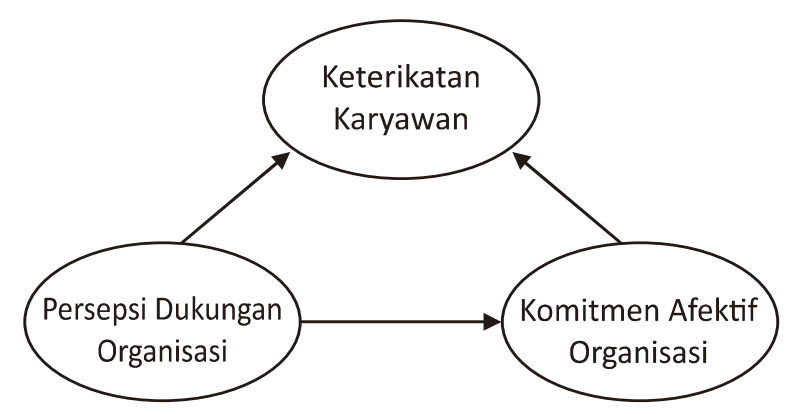

Gambar 1. Hubungan antara Persepsi Dukungan Organisasi, Keterikatan Karyawan dan Komitmen Afektif Organisasi 


\section{Metode}

Penelitian ini dilakukan terhadap 139 orang karyawan yang bekerja di perusahaan pertelevisian di Indonesia, bekerja sebagai karyawan tetap, lama bekerja minimal 1 tahun, serta berusia 23-55 tahun. Usia dibagi ke dalam kelompok sesuai tahap perkembangan karir yang terbagi dalam 4 kategori, yaitu tahap eksplorasi, pembentukan, kemajuan, dan pengelolaan karir (Cohen, 1993). Sementara masa kerja dibagi ke dalam 3 kategori, yaitu tahap eksplorasi, pembentukan, dan pengelolaan karir (Cohen, 1993). Peneliti menggunakan teknik pengambilan sampel dengan metode convenience atau accidental sampling, yaitu responden dipilih karena ketersediaannya dan adanya keinginan secara sukarela untuk berpartisipasi dalam penelitian (Gravetter \& Forzano, 2012). Data diperoleh melalui kuesioner online dengan menggunakan Google form dan kuesioner dalam bentuk hardcopy.

Pada penelitian ini, peneliti menggunakan tiga buah alat ukur. Persepsi dukungan organisasi diukur dengan Survey of Perceived Organizational Support (SPOS) yang diadaptasi dalam Bahasa Indonesia dengan jumlah item 15 butir dan nilai koefisien alfa 0,898 (Eisenberger et al,, 1986; Santoso, 2018). Item-item dalam SPOS terdiri dari 3 faktor pembentuk persepsi dukungan organisasi, yaitu keadilan (fairness), dukungan atasan (supervisory support), serta penghargaan dan kondisi kerja yang baik (organizational rewards and favourable job condition). Contoh item dalam alat ukur SPOS misalnya, "Organisasi sangat peduli terhadap kesejahteraan saya”, "Atasan langsung saya siap membantu ketika saya mengalami suatu masalah, dan "Organisasi mencoba membuat pekerjaan saya semenarik mungkin." Alat ukur SPOS menggunakan skala Likert 1-6, angka 1 menggambarkan respon "Sangat tidak Setuju" terhadap pernyataan kuesioner dan angka 6 menggambarkan respon Sangat Setuju.

Keterikatan karyawan diukur dengan Aon Hewitt Employee Engagement (AHEE) yang diadaptasi ke dalam Bahasa Indonesia oleh (Mangundjaya, Utoyo, \& Wulandari, 2015). Alat ukur ini kemudian dimodifikasi dan diuji coba kembali oleh peneliti. Jumlah item 15 butir dan nilai koefisien alfa sebesar 0,91 . Alat ukur ini terdiri dari 3 faktor yang menggambarkan keterikatan karyawan, yaitu say, stay, dan strive. Contoh item-item dalam alat ukur ini yaitu, "Saya merasa bangga menceritakan kepada orang lain bahwa saya bekerja di perusahaan ini", "Saya berniat menghabiskan usia produktif saya di perusahaan ini" dan "Saya berusaha memberikan kinerja terbaik untuk perusahaan". Alat ukur AHEE menggunakan skala Likert 1-6, angka 1 menggambarkan respon "Sangat tidak Setuju" terhadap pernyataan kuesioner dan angka 6 menggambarkan respon "Sangat Setuju”.

Sementara komitmen afektif organisasi diukur dengan alat ukur yang dikembangkan oleh Seniati (2006) dengan jumlah item 8 butir dan koefisien reliabilitas sebesar 0,78 . Contoh itemitem pada alat ukur ini, yaitu "Saya bersedia bekerja keras melebihi apa yang dikerjakan karyawan lain di perusahaan ini" dan "Saya peduli akan masa depan perusahaan ini sehingga saya berusaha memberikan yang terbaik untuk perusahaan ini". Alat ukur ini menggunakan skala Likert 1-6, angka 1 menggambarkan respon "Sangat tidak Setuju" terhadap pernyataan kuesioner dan angka 6 menggambarkan respon "Sangat Setuju".

Untuk melakukan uji analisis peran mediasi, peneliti menggunakan program PROCESS versi 3.0 yang dikembangkan oleh (Hayes, 2018) dan pengujian ini dilakukan dengan menggunakan IBM SPSS versi 22. 


\section{Hasil}

Pada bagian ini peneliti menjabarkan hasil penelitian berdasarkan pengolahan data statistik dan interpretasinya. Pertama-tama peneliti melakukan analisis variabel demografis responden dengan melakukan uji beda atau uji signifikansi. Tujuan dilakukannya uji beda adalah untuk mengetahui seberapa jauh pengaruh atau perbedaan skor variabel keterikatan karyawan dan komitmen afektif organisasi pada individu berdasarkan kelompok atau kategori tertentu atau dalam hal ini variabel demografis. Berikut adalah penjabaran hasil analisis variabel demografis yang dapat dilihat pada Tabel 1 .

Tabel 1.

Hasil Analisis Variabel Demografis

\begin{tabular}{|c|c|c|c|c|c|c|}
\hline \multirow[t]{2}{*}{ Variabel Demografis } & \multicolumn{3}{|c|}{ Keterikatan Karyawan (EE) } & \multicolumn{3}{|c|}{$\begin{array}{c}\text { Komitmen Afektif } \\
\text { Organisasi (AOC) }\end{array}$} \\
\hline & Mean & SD & Sign. & Mean & SD & Sign. \\
\hline \multicolumn{7}{|l|}{ Usia } \\
\hline$\leq 30$ tahun & 4.30 & 0.64 & \multirow{4}{*}{$0.00 *$} & 4.43 & 0.63 & \multirow{4}{*}{$0.00^{*}$} \\
\hline $31-35$ tahun & 4.36 & 0.59 & & 4.41 & 0.57 & \\
\hline $36-40$ tahun & 4.74 & 0.68 & & 4.84 & 0.76 & \\
\hline >40tahun & 4.73 & 0.69 & & 5.11 & 0.45 & \\
\hline \multicolumn{7}{|l|}{ Lama bekerja } \\
\hline $1-4$ tahun & 4.27 & 0.65 & \multirow{3}{*}{$0.00^{*}$} & 4.47 & 0.69 & \multirow{3}{*}{$0.00^{*}$} \\
\hline $5-8$ tahun & 4.44 & 0.58 & & 4.47 & 0.54 & \\
\hline$\geq 9$ tahun & 4.76 & 0.68 & & 5.02 & 0.60 & \\
\hline \multicolumn{7}{|l|}{ Jabatan } \\
\hline Kepala departemen / manager & 4.85 & 0.69 & \multirow{3}{*}{0.05} & 5.19 & 0.59 & \multirow{3}{*}{$0.00 *$} \\
\hline Kepala seksi / supervisor & 4.45 & 0.62 & & 4.73 & 0.58 & \\
\hline Staf & 4.40 & 0.67 & & 4.46 & 0.66 & \\
\hline
\end{tabular}

* signifikansi pada $\mathrm{p}<0.05$

Berdasarkan pengolahan data demografis, responden terbanyak berjenis kelamin laki-laki (91 orang, 65,60\%), usia di bawah 30 tahun (58 orang, 41,70\%) dan lama bekerja 1-4 tahun (53 orang, 38,10\%). Sebagian besar responden menjabat sebagai staf (73 orang, 52,50\%) dan berada pada jenjang pendidikan S1 (104 orang, 74,80\%). Tabel 1 menunjukkan hasil analisis variabel demografis yang menunjukkan bahwa variabel demografis tidak berpengaruh terhadap persepsi dukungan organisasi. Sementara usia dan lama bekerja memengaruhi keterikatan karyawan secara signifikan. Tabel 1 menunjukkan bahwa individu dengan kategori usia 36-40 tahun dan di atas 40 tahun memiliki nilai rata-rata tertinggi. Begitu juga dengan individu yang memiliki lama bekerja di atas 9 tahun memiliki nilai rata-rata tertinggi. Hal ini menunjukkan bahwa semakin bertambah usia dan lama bekerja, maka level keterikatan karyawan juga akan meningkat. Penemuan ini sejalan dengan hasil penelitian yang sebelumnya dilakukan oleh Federman (2009). Hasil analisis ini juga menunjukkan bahwa usia, lama bekerja dan jabatan memengaruhi komitmen afektif organisasi secara signifikan. Dengan kata lain, semakin bertambah usia, lama bekerja dan meningkatnya level jabatan, maka akan semakin meningkat pula komitmen afektif organisasi. Hasil ini mendukung penelitian empiris yang dilakukan oleh (Pourghaz et al, 2011) yang menyatakan hal yang sama. 
Tabel 2.

Hasil Analisis Interkorelasi

\begin{tabular}{lccccccc}
\hline \multirow{2}{*}{ Variabel } & \multirow{2}{*}{ Mean } & \multicolumn{2}{c}{ POS } & \multicolumn{2}{c}{ EE } & \multicolumn{2}{c}{ AOC } \\
\cline { 3 - 8 } & & $r$ & Sig. & $r$ & Sig. & $r$ & Sig \\
\hline POS & 4.40 & 1 & - & 0.76 & $0.00^{*}$ & 0.61 & $0.00^{*}$ \\
EE & 4.48 & 0.76 & $0.00^{*}$ & 1 & - & 0.68 & $0.00^{*}$ \\
AOC & 4.65 & 0.61 & $0.00^{*}$ & 0.68 & $0.00^{*}$ & 1 & - \\
\hline
\end{tabular}

*signifikansi pada $\mathrm{p}<0.05$, Persepsi Dukungan Organisasi (POS), Keterikatan Karyawan (EE),

Komitmen Afektif Organisasi (AOC)

Pada bagian berikutnya, peneliti melakukan analisis interkorelasi. Hal ini dilakukan untuk mengetahui apakah masing-masing variabel memiliki korelasi satu sama lain, bagaimana arah korelasinya dan seberapa besar korelasi tersebut. Lebih lanjut, hasil ini dijabarkan pada Tabel 2.

Tabel 2 menunjukkan nilai rata-rata setiap variabel dan hasil analisis interkorelasi yang menggambarkan hubungan antara variabel persepsi dukungan organisasi, keterikatan karyawan, dan komitmen afektif organisasi. Tabel tersebut menunjukkan nilai rata-rata variabel persepsi dukungan organisasi sebesar 4,40, keterikatan karyawan dengan nilai rata-rata 4,48, dan nilai rata-rata komitmen afektif organisasi sebesar 4,65. Tabel tersebut juga menunjukkan adanya korelasi positif yang signifikan antara persepsi dukungan organisasi dengan keterikatan karyawan sebesar 76\%; korelasi antara persepsi dukungan organisasi dengan komitmen afektif organisasi sebesar 61\%; dan korelasi antara keterikatan karyawan dengan komitmen afektif organisasi sebesar 68\%.

Selanjutnya peneliti membahas mengenai analisis peran mediasi dengan menggunakan teknik PROCESS yang dikembangkan oleh Hayes (2018). Analisis ini dilakukan untuk mengetahui efek mediasi dari variabel keterikatan karyawan terhadap hubungan antara persepsi dukungan organisasi dan komitmen afektif organisasi. Hasil analisis mediasi dijabarkan pada Tabel 3 .

Tabel 3.

Model Koefisien Penelitian Persepsi Dukungan Organisasi (POS), Keterikatan Karyawan (EE) dan Komitmen Afektif Organisasi (AOC)

\begin{tabular}{|c|c|c|c|c|c|c|c|c|c|c|}
\hline \multirow{3}{*}{ Antesenden } & \multicolumn{10}{|c|}{ Konsekuen } \\
\hline & \multicolumn{6}{|c|}{$M(E E)$} & \multicolumn{4}{|c|}{$\mathrm{Y}(\mathrm{AOC})$} \\
\hline & & $\beta$ & SE & $\mathrm{t}$ & $p$ & & $\beta$ & SE & $\mathrm{t}$ & $p$ \\
\hline$X(P O S)$ & $a$ & 0.78 & 0.06 & 13.46 & $<0.05$ & $c^{\prime}$ & 0.12 & 0.05 & 2.40 & $<0.05$ \\
\hline $\mathrm{M}(\mathrm{EE})$ & & - & - & - & - & $b$ & 0.27 & 0.05 & 5.36 & $<0.05$ \\
\hline \multirow[t]{3}{*}{ constant } & $i_{M}$ & 15.97 & 3.85 & 4.15 & $<0.05$ & $i_{Y}$ & 10.86 & 2.40 & 4.52 & $<0.05$ \\
\hline & \multicolumn{6}{|c|}{$R^{2}=0.57$} & \multicolumn{4}{|c|}{$R^{2}=0.474$} \\
\hline & \multicolumn{6}{|c|}{$\mathrm{F}(1,137)=181.28, p<0.05$} & \multicolumn{4}{|c|}{$F(2,136)=66.61, p<0.05$} \\
\hline Total effect & & \multicolumn{9}{|c|}{$0.33, \mathrm{LLCl}=0.26, \mathrm{ULCl}=0.41$} \\
\hline Direct effect & & \multicolumn{9}{|c|}{$0.12, \mathrm{LLCl}=0.22, \mathrm{ULCl}=0.23$} \\
\hline Indirect effect & & \multicolumn{9}{|c|}{0.21, BootSE $=0.04$, BootLLCI $=0.13$, BootULCI $=0.30$} \\
\hline
\end{tabular}


Berdasarkan hasil analisis peran mediasi pada Tabel 3, terdapat hubungan positif yang signifikan antara persepsi dukungan organisasi dan keterikatan karyawan $(\beta=0,78$; $\mathrm{SE}=0,06 ; \mathrm{t}=13,46$; $\mathrm{LLCI}=0,66 ; \mathrm{ULCI}=0,89 ; \mathrm{p}<.005$ ); persepsi dukungan organisasi dan komitmen afektif organisasi $(\beta=0,12 ; \mathrm{SE}=0.05 ; \mathrm{t}=2.40$; $\mathrm{LLCI}=0,02 ; \mathrm{ULCI}$ $=0,23, p<0,005)$; serta keterikatan karyawan dan komitmen afektif organisasi $(\beta=0,27$; $\mathrm{SE}=0,05$; $\mathrm{t}=5,36$; LLCI =0,17; ULCI =0,37; p < 0,005). Selanjutnya, hubungan antara persepsi dukungan organisasi dan komitmen afektif organisasi yang dimediasi keterikatan karyawan juga menunjukkan hasil yang signifikan $(\beta=0,21$; BootSE $=0,04$; BootLLCI = 0,13; BootULCI = 0,30; $p<0,005$ ).

\section{Diskusi}

Penelitian ini dilakukan untuk menguji peran keterikatan karyawan terhadap hubungan antara persepsi dukungan organisasi dan komitmen afektif organisasi. Sebelumnya peneliti telah melakukan uji korelasi dan hasilnya menunjukkan bahwa ketiga variabel memiliki korelasi positif yang signifikan, seperti yang ada pada penjelasan Tabel 2. Selanjutnya, berdasarkan Tabel 3, model penelitian mediasi antara ketiga variabel menunjukkan hasil yang signifikan. Hasil tersebut menunjukkan adanya pengaruh langsung terhadap hubungan antara persepsi dukungan organisasi dan komitmen afektif organisasi. Hasil penelitian juga menunjukkan adanya pengaruh tidak langsung antara persepsi dukungan organisasi dan komitmen afektif organisasi melalui keterikatan karyawan. Dengan demikian, dapat disimpulkan bahwa keterikatan karyawan memediasi secara parsial hubungan antara persepsi dukungan organisasi dan komitmen afektif organisasi.

Hasil ini didukung oleh penelitian-penelitian sebelumnya. Salah satu penelitian yang dilakukan terhadap aparat kepolisian di Belanda menunjuk- kan bahwa komitmen afektif organisasi memiliki korelasi positif dengan keterikatan kerja (work engagement), sehingga dapat mendorong individu melakukan peran tambahan (extra-role behavior) (Gelderen \& Bik, 2016). Penelitian lainnya menunjukkan adanya peran keterikatan kerja (work engagement) yang memediasi hubungan antara persepsi dukungan organisasi dan komitmen afektif organisasi (Gokul, Sridevi, \& Srinivasan, 2012). Penelitian tersebut menggunakan dasar teori keterikatan (engagement) yang terdiri dari 3 dimensi, yaitu vigor, absorption, dan dedication (Maslach, Schaufeli, \& Leiter, 2001). Meskipun hasil penelitian menunjukkan adanya hubungan antara persepsi dukungan organisasi dan komitmen afektif organisasi melalui keterikatan (engagement), tetapi hanya dimensi dedication yang memengaruhi hubungan mediasi tersebut. Sementara untuk dimensi vigor dan absorption tidak memengaruhi komitmen afektif organisasi secara signifikan.

Lebih lanjut, terkait permasalahan kondisi kerja pada karyawan pertelevisian seperti yang dijelaskan pada latar belakang penelitian, perubahan yang terjadi di dalam organisasi dalam bentuk merger dan akuisisi diyakini sebagai salah satu faktor penyebab. Oleh sebab itu kelincahan organisasi (agility) untuk beradaptasi dengan lingkungan perlu ditingkatkan (Aon Hewitt, 2018). Salah satu penelitian menunjukkan bahwa kelincahan organisasi berhubungan dengan komitmen organisasi (Chamanifard, Nikpour, Chamanifard, \& Nobarieidishe, 2015). Kelincahan organisasi dalam menyesuaikan diri terhadap tantangan yang muncul akan menunjukkan keberhasilan organisasi. Hal ini kemudian membangun citra yang baik bagi organisasi, sehingga dapat meningkatkan keterikatan karyawan (Aon Hewitt, 2018) dan komitmen organisasi (Chamanifard et al., 2015), terutama komitmen afektif organisasi. Alasannya karena komitmen afektif organisasi dapat mem- 
buat individu lebih menghargai nilai-nilai perusahaan (Beheshtifar \& Herat, 2013), dan patuh pada norma dan praktik kebijakan organisasi (Jena et al., 2017), sehingga hal ini dapat mendukung keberhasilan proses perubahan yang terjadi di dalam organisasi.

Pada penelitian tentang kondisi perubahan organisasi di Indonesia dalam skala besar, ditemukan bahwa praktik kebijakan departemen SDM menjadi salah satu masalah utama (Mangundjaya, 2014). Masalah ini berkaitan dengan keadilan organisasi, terutama yang berhubungan dengan kompensasi serta pengembangan karir, dan merupakan bagian atau komponen persepsi dukungan organisasi (Mangundjaya, 2014; Wayne et al., 1997). Penelitian tentang peran departemen SDM telah lama dilakukan dan menunjukkan adanya korelasi positif yang signifikan dengan komitmen afektif organisasi (Gaertner \& Nollen, 1989); (Ogilvie, 1986), dan terus dikembangkan.

Penelitian berikutnya menyatakan bahwa manajemen perlu mengembangkan sejumlah kebijakan melalui departemen SDM dan mensosialisasikan perilaku manajerial yang dapat mengarahkan kepada persepsi dukungan organisasi, sehingga dapat menurunkan risiko beban kerja yang berlebihan (Caesens, Stinglhamber, \& Ohana, 2016). Selain itu, persepsi dukungan organisasi dapat menumbuhkan kepercayaan (trust) individu kepada organisasi dan berdampak pada kesiapan individu untuk berubah (Gigliotti, Vardaman, Marshall, \& Gonzalez, 2018).

Selain hubungan positif yang signifikan antara ketiga variabel dan hubungan melalui peran mediasi, terdapat beberapa penelitian yang membahas mengenai pengaruh dari faktor demografis terhadap komitmen afektif organisasi dan keterikatan karyawan. Hasil penelitian pada Tabel 1 menunjukkan bahwa usia, lama bekerja, dan jabatan memiliki pengaruh terhadap komitmen afektif organisasi. Karyawan yang berusia di atas 40 tahun, telah bekerja di atas 9 tahun dan menjabat sebagai kepala departemen atau manager memiliki tingkat komitmen afektif organisasi yang paling tinggi. Hal ini dapat dijelaskan dengan argumen bahwa kelekatan secara emosional terhadap organisasi muncul karena lama bekerja yang terus bertambah, sehingga menyebabkan individu sulit untuk meninggalkan organisasi (Meyer \& Allen, 1997). Hasil ini mendukung penelitian sebelumnya yang menunjukkan bahwa terdapat hubungan yang signifikan antara usia dengan ketiga komponen komitmen organisasi (Jena et al, 2017). Semakin bertambahnya usia dan lama bekerja, hal ini juga diikuti dengan jenjang karir yang terus berkembang.

Selain itu, pada penelitian ini diketahui bahwa persepsi dukungan organisasi tidak dipengaruhi oleh faktor demografis seperti usia maupun lama bekerja. Sementara untuk variabel keterikatan karyawan, usia, dan lama bekerja memiliki pengaruh yang signifikan. Individu yang berada pada tahap perkembangan kemajuan karir (36-40 tahun) dan individu dengan lama bekerja di atas 9 tahun atau berada pada tahap pengelolaan karir, memiliki tingkat keterikatan karyawan yang lebih tinggi. Artinya keterikatan karyawan akan semakin kuat seiring dengan bertambahnya usia dan lama bekerja. Hal ini diperkuat dengan penelitian yang menunjukkan bahwa karyawan dengan usia 60 tahun ke atas memiliki tingkat keterikatan karyawan yang lebih tinggi dibandingkan dengan karyawan dengan usia yang lebih muda (Robinson, Perryman, \& Hayday, 2004). Begitu pula dengan penelitian lainnya yang juga menunjukkan bahwa karyawan yang lebih tua dari segi usia memiliki tingkat keterikatan karyawan yang lebih tinggi dibandingkan dengan karyawan yang lebih muda (Pitt-Catsouphes, Smyer, Matz-costa, \& Kane, 2007). 
Hasil penelitian di atas menunjukkan bahwa umumnya karyawan usia muda memiliki level keterikatan karyawan yang lebih rendah dibandingkan dengan karyawan senior. Untuk itu perlu diketahui bahwa karyawan usia muda dengan usia produktif memiliki karakteristik yang berbeda dengan generasi karyawan yang lebih senior. Penelitian terbaru mengenai keterikatan kerja (work engagement) pada karyawan generasi milenial, menunjukkan bahwa kebosanan kerja dan kemandirian kerja berperan dalam memengaruhi keterikatan kerja (Forastero, Sjabadhyni, \& Mustika, 2018). Hasil penelitian ini menunjukkan bahwa kemandirian kerja (job autnomy) memiliki peran yang penting dalam meningkatkan keterikatan kerja dan dapat menurunkan kebosanan kerja.

Berdasarkan berbagai penelitian yang telah dilakukan, umumnya selalu terdapat hubungan positif yang signifikan antara persepsi dukungan organisasi, keterikatan karyawan, maupun komitmen afektif organisasi. Meskipun demikian, penelitian yang dilakukan untuk menguji hubungan antara persepsi dukungan organisasi dengan komitmen afektif organisasi melalui peran mediasi keterikatan karyawan masih sangat terbatas. Oleh sebab itu, hasil penelitian ini dapat menjadi salah satu referensi terkait dengan variabel komitmen afektif organisasi, keterikatan karyawan dan persepsi dukungan organisasi, yang merupakan bagian dari bidang psikologi industri dan organisasi.

Secara keseluruhan, meskipun hasil penelitian menunjukkan angka signifikansi yang baik, tetapi masih terdapat beberapa hal yang menjadi keterbatasan pada penelitian ini. Salah satunya terkait dengan pengambilan sampel. Peneliti menggunakan teknik pengambilan sampel melalui convenience sampling, yaitu teknik pengambilan sampel karena adanya faktor kemudah- an ketersediaan sampel (Gravetter \& Forzano, 2012). Oleh sebab itu, pengambilan data mayoritas dilakukan di salah satu perusahaan pertelevisian karena faktor kemudahan tersebut, sehingga 73,38\% sampel berasal dari satu perusahaan yang sama. Sementara $26,62 \%$ responden lainnya tersebar dari berbagai perusahaan pertelevisian lainnya. Dapat dikatakan bahwa penyebaran responden terfokus hanya pada salah satu perusahaan pertelevisian di Indonesia.

Selain itu, umumnya semua perusahaan pertelevisian di Indonesia memiliki kantor pusat yang berada di wilayah Jakarta, sehingga sampel dalam penelitian ini belum menjangkau perusahaan pertelevisian di daerah-daerah lainnya. Untuk itu, dalam penelitian berikutnya, perlu dilakukan penelitian yang lebih luas dengan memperhatikan batasan-batasan yang muncul dalam penelitian ini. Kelemahan lain dalam penelitian ini adalah penggunaan alat ukur yang berupa self-report, sehingga menimbulkan risiko adanya social desirability atau kecenderungan seseorang untuk memberikan pernyataan yang lebih disukai secara sosial. Hal ini juga dapat mengacu pada common method bias yang dapat terjadi karena respon yang diberikan responden tidak mencerminkan konstruk yang ingin diukur atau responden cenderung menyetujui pernyataan positif dan tidak menyetujui pernyataan negatif (Podsakoff, MacKenzie, Lee, \& Podsakoff, 2003).

\section{Simpulan}

Terdapat beberapa simpulan yang dapat ditarik pada penelitian ini. Seperti yang telah dijelaskan sebelumnya bahwa variabel keterikatan karyawan memiliki peran dalam memediasi hubungan antara persepsi dukungan organisasi dan komitmen afektif organisasi. Hasil ini telah didukung oleh beberapa penelitian. 
Meskipun demikian, hasil penelitian juga menunjukkan bahwa hubungan langsung antara persepsi dukungan organisasi dan komitmen afektif organisasi dapat terjadi, tanpa adanya peran mediasi dari keterikatan karyawan. Hal ini tentunya perlu dikaji lebih lanjut pada penelitian berikutnya. Hasil penelitian juga menunjukkan bahwa faktor demografis seperti usia dan lama bekerja memengaruhi keterikatan karyawan. Sementara faktor demografis seperti usia, lama bekerja dan jabatan memengaruhi komitmen afektif organisasi.

\section{Saran}

Penelitian ini diharapkan dapat menjadi salah satu referensi terkait dengan model penelitian yang meneliti tentang hubungan antara persepsi dukungan organisasi dan komitmen afektif organisasi yang dimediasi oleh keterikatan karyawan, terutama dalam konteks karyawan yang bekerja di industri pertelevisian. Terkait dengan kondisi kerja karyawan pertelevisian yang unik, masih banyak variabel penelitian lainnya yang dapat diinvestigasi lebih lanjut, mengingat penelitian mengenai variabel psikologis di industri ini masih belum banyak dilakukan, terutama di Indonesia. Dengan adanya penelitian ini tentunya dapat menjadi masukan bagi industri pertelevisian untuk melakukan program pengembangan organisasi.

Pada penelitian berikutnya, peneliti menyarankan untuk mengambil jumlah sampel yang lebih besar agar hasil penelitian dapat digeneralisasikan. Pengambilan sampel juga disarankan agar tidak hanya berfokus pada perusahaan pertelevisian yang ada di daerah Jakarta, tetapi juga televisi daerah yang ada di Indonesia. Terkait dengan adanya risiko terjadinya social desirability dan common method bias pada alat ukur, peneliti menyarankan agar dapat dilakukan pengambilan data dari sumber dan waktu yang berbeda guna menguji masing-masing variabel dan membandingkannya dengan hasil penelitian (Podsakoff et al., 2003).

Hasil penelitian yang menunjukkan adanya peran variabel demografis terhadap komitmen afektif organisasi dan keterikatan karyawan dapat dimanfaatkan oleh organisasi untuk meningkatkan kedua variabel tersebut. Hal ini dapat dilakukan dengan cara mengindentifikasi individuindividu sesuai dengan karakteristik demografis tersebut dan melakukan pengukuran terhadap skor variabel komitmen afektif organisasi dan keterikatan karyawan. Selanjutnya, individuindividu yang telah terindentifikasi memiliki skor komitmen afektif organisasi dan keterikatan karyawan yang tinggi, dapat diikutsertakan dalam program role model bagi karyawan lain melalui kegiatan sharing, coaching atau mentoring. Hal ini diharapkan dapat membantu karyawan lain yang memerlukan pengembangan komitmen afektif organisasi dan keterikatan karyawan.]

\section{Daftar Pustaka}

Ahlowalia, S., Tiwary, D., \& Jha, A. (2014). Employee engagement: A structured theoretical review. The International Journal of Business \& Management, 2(6), 309.

Aon Hewitt. (2018). 2018 Trends in global employee engagement. Retrieved from https://de.statista. com/statistik/studie/id/52986/dokument/studie-zur-mitarbeitermotivation-weltweit-2018/

Azeem, S. M. (2010). Personality hardiness, job involvement and job burnout among teachers. International Journal of Vocational and Technical Education, 2(3), 36-40. 
Beheshtifar, M., \& Herat, B. H. (2013). To promote employees commitment via perceived organizational support. International Journal of Academic Research in Business and Social Sciences, 3(1), 306314.

Caesens, G., Stinglhamber, F., \& Ohana, M. (2016). Perceived organizational support and well-being: a weekly study. Journal of Managerial Psychology, 31(7), 1214-1230. https://doi.org/10.1108/ JMP-01-2016-0002

Chamanifard, R., Nikpour, A., Chamanifard, S., \& Nobarieidishe, S. (2015). Impact of organizational agility dimensions on employee's organizational commitment in Foreign Exchange Offices of Tejarat Bank, Iran. Special Issue on New Dimensions in Economics, Accounting and Management, 4(1), 199-207.

Coffman, C., Gonzalez-Molina, G., \& Gopal, A. (2002). Follow this path: How the world's greatest organizations drive growth by unleashing human potential. New York, NY: Business Plus.

Cohen, A. (1993). Age and tenure in relation to organizational commitment: A meta analysis. Basic And Applied Social Psychology, 14(2), 143-159.

Cropanzano, R., \& Mitchell, M. S. (2005). Social exchange theory: An interdisciplinary review. Journal of Management, 31(6), 874-900.

Dai, K., \& Qin, X. (2016). Perceived organizational support and employee engagement: Based on the research of organizational identification and organizational justice. Open Journal of Social Sciences, 4(12), 46. https://doi.org/10.4236/jss.2016.412005

Eisenberger, R., Armeli, S., Rexwinkel, B., Lynch, P. D., \& Rhoades, L. (2001). Reciprocation of perceived organizational support. Journal of Applied Psychology, 86(1), 42-51. https://doi.org/ 10.1037/0021-9010.86.1.42

Eisenberger, R., Fasolo, P., \& Davis-LaMastro, V. (1990). Perceived organizational support and employee diligence, commitment, and innovation. Journal of Applied Psychology, 75(1), 51. https://doi.org/10.1037//0021-9010.75.1.51

Eisenberger, R., Huntington, R., Hutchison, S., \& Sowa, D. (1986). Perceived organizational support. Journal of Applied Psychology, 71(3), 500-507.

Federman, B. (2009). Employee engagement: A roadmap for creating profits, optimizing performance, and increasing loyalty. San Francisco: John Wiley \& Sons Inc.

Forastero, A., Sjabadhyni, B., \& Mustika, M. D. (2018). What millennials want: How to optimize their work. Psikohumaniora: Jurnal Penelitian Psikologi, 3(1), 1-16. https://doi.org/10.21580/ pjpp.v3i1.2489

Gaertner, K. N., \& Nollen, S. D. (1989). Career experiences, perceptions of employment practices, and psychological commitment to the organization. Human Relations, 42(11), 975-991.

Gelderen, B. R. van, \& Bik, L. W. (2016). Affective organizational commitment, work engagement and service performance among police officers. Policing: An International Journal of Police Strategies \& Management, 39(1), 206-221. https://doi.org/10.1108/PIJPSM-10-2015-0123

Gigliotti, R., Vardaman, J., Marshall, D. R., \& Gonzalez, K. (2018). The role of perceived organizational support in individual change readiness. Journal of Change Management, 1-15. https://doi.org/ 10.1080/14697017.2018.1459784

Gokul, A., Sridevi, G., \& Srinivasan, P. T. (2012). The relationship between perceived organizational support, work engagement and affective commitment. AMET International Journal of 
Management, 4(July-Dec). Retrieved from http://www.ametjournal.com/attachment/ ametjournal-4/Dev-Article-4-Gokul.pdf

Gravetter, F. J., \& Forzano, L.-A. B. (2012). Research methods for the behavioral sciences (4th ed.). Belmont, CA: Wadsworth Gengage Learning.

Hayes, A. F. (2018). Introduction to mediation, moderation, and conditional process analysis: A regression-based approach (2nd ed.). New York: Guilford Publications.

Hewitt Associates. (2004). Employee engagement higher at double-digit growth companies: Double-digit growth and engagement (Research brief). Illionis. Retrieved from http://www. connectthedotsconsulting.com/documents/Engagement/EE Engagement at DD Growth Companies 2012.pdf

Jena, L. K., Bhattacharyya, P., \& Pradhan, S. (2017). Employee engagement and affective organizational commitment: Mediating role of employee voice among Indian service sector employees. Vision: The Journal of Business Perspective, 21(4), 356-366. https://doi.org/10.1177/ 0972262917733170

Kahn, W. A. (1990). Psychological conditions of personal engagement and disengagement at work. Academy of Management Journal, 33(4), 692-724. https://doi.org/10.2307/256287

Kobasa, S. C., Maddi, S. R., \& Kahn, S. (1982). Hardiness and health: A prospective study. Journal of Personality and Social Psychology, 42(1), 168-177. https://doi.org/10.1037/00223514.42.1.168

Lynch, P. D., Eisenberger, R., \& Armeli, S. (1999). Perceived organizational support: Inferior versus superior performance by wary employees. Journal of Applied Psychology, 84(4), 467-483. https://doi.org/10.1037/0021-9010.84.4.467

Mangundjaya, W. L. H. (2014). The role of employee engagement on the commitment to change (During large-scale organizational change in Indonesia). IJMT: International Journal of Multidisciplinary Thought, 4(1), 375-384.

Mangundjaya, W. L. H., Utoyo, D. B., \& Wulandari, P. (2015). The role of leadership and employee's condition on reaction to organizational change. Procedia-Social and Behavioral Sciences, 172, 471-478.

Maslach, C., Schaufeli, W. B., \& Leiter, M. P. (2001). Job burnout. Annual Review of Psychology, 52(1), 397422. https://doi.org/10.1146/annurev.psych.52.1.397

Mercurio, Z. A. (2015). Affective commitment as a core essence of organizational commitment: An integrative literature review. Human Resource Development Review, 14(4), 389-414. https://doi.org/10.1177/1534484315603612

Meyer, J. P., \& Allen, N. J. (1987). Organizational commitment: Toward a three-component model. London: Department of Psychology, University of Western Ontario.

Meyer, J. P., \& Allen, N. J. (1990). The measurement and antecedents of affective, continuance and normative commitment to the organization. Journal of Occupational Psychology, 63(1), 1-18. https://doi.org/10.1111/j.2044-8325.1990.tb00506.x

Meyer, J. P., \& Allen, N. J. (1991). A three-component conceptualization of organizational commitment. Human Resource Management Review, 1(1), 61-89. https://doi.org/10.1016/1053-4822(91) 90011-Z

Meyer, J. P., \& Allen, N. J. (1997). Commitment in the workplace: Theory, research, and application. Thousand Oaks, CA: SAGE Publications, Inc. https://doi.org/10.4135/9781452231556 
Meyer, J. P., Stanley, D. J., Herscovitch, L., \& Topolnytsky, L. (2002). Affective, continuance, and normative commitment to the organization: A meta-analysis of antecedents, correlates, and consequences. Journal of Vocational Behavior, 61(1), 20-52. https://doi.org/10.1006/jvbe.2001.1842

Nugroho, Y., Putri, D. A., \& Laksmi, S. (2012). Mapping the landscape of the media industry in contemporary Indonesia. Jakarta: Centre for Innovation Policy and Governance \& Ford Foundation. Retrieved from https://www.escholar.manchester.ac.uk/api/datastream? publicationPid=uk-ac-man-scw:168565\&datastreamId=FULL-TEXT.PDF

O'Donohue, W., \& Nelson, L. (2014). Alienation: An old concept with contemporary relevance for human resource management. International Journal of Organizational Analysis, 22(3), 301-316. https://doi.org/10.1108/ijoa-01-2012-0541

Ogilvie, J. R. (1986). The role of human resource management practices in predicting organizational commitment. Group \& Organization Studies, 11(4), 335-359. https://doi.org/10.1177/ 0364108286114003

Pitt-Catsouphes, M., Smyer, M. A., Matz-costa, C., \& Kane, K. (2007). The national study report: Phase II of the national study of business strategy and workforce development (Vol. 4). Boston: The Center on Aging \& Work - Boston College.

Podsakoff, P. M., MacKenzie, S. B., Lee, J. Y., \& Podsakoff, N. P. (2003). Common method biases in behavioral research: A critical review of the literature and recommended remedies. Journal of Applied Psychology, 88(5), 879-903. https://doi.org/10.1037/0021-9010.88.5.879

Posthuma, R. A., Campion, M. C., Masimova, M., \& Campion, M. A. (2013). A high performance work practices taxonomy: Integrating the literature and directing future research. Journal of Management, 39(5), 1184-1220. https://doi.org/10.1177/0149206313478184

Pourghaz, A., Tamini, B. K., \& Karamad, A. (2011). Do demographic characteristics make a difference to job satisfaction, organizational commitment and burnout among travel agency drivers? A case study in Iran. Journal of Basic and Applied Scientific Research, 1(8), 916-923.

Rhoades, L., \& Eisenberger, R. (2002). Perceived organizational support: A review of the literature. Journal of Applied Psychology, 87(4), 698-714. https://doi.org/10.1037/0021-9010.87.4.698

Rhoades, L., Eisenberger, R., \& Armeli, S. (2001). Affective commitment to the organization: The contribution of perceived organizational support. Journal of Applied Psychology, 86(5), 825. https://doi.org/10.1037/0021-9010.86.5.825

Robinson, D., Perryman, S., \& Hayday, S. (2004). The drivers of employee engagement. Brighton, UK: Institute For Employment Studies. Retrieved from www.employment-studies.co.uk/ pubs/report.php?id=447

Santoso, A. R. (2018). Workshop coaching atasan untuk meningkatkan persepsi pegawai terhadap dukungan atasan dan komitmen afektif untuk berubah. Universitas Indonesia.

Sanusi. (2013). 200 karyawan Trans TV dikabarkan resign, apa jawaban Trans Corp? Retrieved from http://www.tribunnews.com/bisnis/2013/06/03/200-karyawan-trans-tv-dikabarkanresign-apa-jawaban-trans-corp

Schmidt, K.-H. (2007). Organizational commitment: A further moderator in the relationship between work stress and strain? International Journal of Stress Management, 14(1), 26. https://doi.org/ 10.1037/1072-5245.14.1.26

Seniati, L. (2006). Pengaruh masa kerja, trait kepribadian, kepuasan kerja, dan iklim psikologis terhadap komitmen dosen pada Universitas Indonesia. Makara: Human Behavior Studies in Asia, 10(2). https://doi.org/10.7454/MSSH 
Tepper, B. J., \& Taylor, E. C. (2003). Relationships among supervisors' and subordinates' procedural justice perceptions and organizational citizenship behaviors. Academy of Management Journal, 46(1), 97-105. https://doi.org/10.2307/30040679

Viswesvaran, C., Sanchez, J. I., \& Fisher, J. (1999). The role of social support in the process of work stress: A meta-analysis. Journal of Vocational Behavior, 54(2), 314-334. https://doi.org/10.1006/ jvbe.1998.1661

Wardhana, A. K. (2018). Stress kerja: Penyebab, dampak dan solusinya (Studi kasus pada karyawan NET Yogyakarta). Uniersitas Islam Indonesia, Yogyakarta.

Wayne, S. J., Shore, L. M., \& Liden, R. C. (1997). Perceived organizational support and leader-member exchange: A social exchange perspective. Academy of Management Journal, 40(1), 82-111. https://doi.org/10.2307/257021 